\title{
Introduction
}

[One] cannot but admire the striking example of democracy which this small multi-racial and multilingual nation has set for the world. Nor can [one] fail to give her credit for the loyalty with which she has cooperated with other nations in the past. Not only have various international bureaus been located at Bern, but Switzerland continued to give hospitality to the League of Nations when potentially hostile armies were massed on all her frontiers. The whole world expects Switzerland to hew the line of legal propriety, to chart her course with meticulous regard for her obligations under international law. ${ }^{1}$

The above quote, written by Manley O Hudson, dates back to 1947. Today, more than seven decades later, Hudson's optimistic remarks about Switzerland's expected compliance with international law leave us wondering how the practice of the Swiss authorities has evolved. Has Switzerland indeed been 'chart[ing] her course with meticulous regard for her obligations under international law'?

In this book, I examine how Swiss courts, but also domestic courts in general, do and must interpret ${ }^{3}$ international law. For this purpose, I analyze whether they comply with what international law requires from States when they interpret their international legal obligations. I also assess whether Swiss courts' interpretations are predictable, clear, and consistent. I then suggest how to improve this domestic judicial practice from these two perspectives.

The two basic claims guiding my study are the following. First, Switzerland and other States, when interpreting international law via their organs,

1 Manley O Hudson, 'Switzerland and the International Court of Justice' (1947) 41 American Journal of International Law 866, $867 \mathrm{f}$.

2 See ibid 868.

3 In Chapter 2 (infra), I discuss the variety of activities involved in this context.

(C) ODILE AMMANN, 2020 | DOI:10.1163/9789004409873_002

This is an open access chapter distributed under the terms of the CC-BY-NC 4.0 License: le Ammann - 9789004409873 
including their courts, must abide by the interpretative methods required by international law. They must use these methods as guides in their interpretative process. Indeed, courts' adherence to the law's interpretative methods is a condition of the legality of their decisions. Second, courts, qua legal reasoners, must interpret the law as predictably, clearly, and consistently as possible. The predictability, clarity, and consistency of domestic courts' interpretations of international law matter because these virtues support legality. Said virtues also matter because they influence the extent to which domestic judgments constitute reliable and helpful means for ascertaining international law.

This two-pronged argument may seem to be a truism. Of course, judges must abide by the law when they interpret it. And of course, they must interpret it well. Why, then, state the obvious? Some readers, when flipping (or scrolling!) through the pages of this book, will likely think something along the lines of what us Supreme Court Justice Felix Frankfurter wrote about statutory interpretation:

No matter how one states the problem of statutory construction, for me at least it does not carry its own answer. Though my business throughout most of my professional life has been with statutes, I come to you emptyhanded. I bring no answers. I suspect the answers to the problems of an art are in its exercise. Not that one does not inherit, if one is capable of receiving it, the wisdom of the wise. But I confess unashamedly that I do not get much nourishment from books on statutory construction, and I say this after freshly reexamining them all, scores of them. ${ }^{4}$

Justice Frankfurter's statement about us statutory interpretation can be extrapolated to any analysis of interpretative methods. As I will argue, the basic methods of legal interpretation are the same across domestic legal orders and in international law, despite the differences that exist between domestic and international lawmaking.

In some respects, Frankfurter is undoubtedly right. One cannot master judicial interpretation only by reading the theoretical accounts of interpretation he alludes to. On the other hand, scholarly analyses of judicial interpretation are not comparable to books that teach us how to play the guitar. An argument as to how judicial interpretation must be conducted is an integral part

4 Felix Frankfurter, 'Some Reflections on the Reading of Statutes' (1947) 47 Columbia Law Review 527,530 . 
of legal practice. It contributes to its justification and improvement. Moreover, the domestic (including the Swiss) case law shows that books on judicial interpretation are more urgently needed than we might think. Compliance with the law's interpretative methods and the virtues of predictability, clarity, and consistency is often unmet in practice, especially when it comes to international law.

Since 1954, the share of published rulings in which the Swiss Federal Tribunal mentions international law has more than tripled. ${ }^{5}$ Analogous trends are witnessed in other jurisdictions. International law poses interpretative challenges for judges, due to its frequent vagueness and the stakes involved for States. However, as I will argue in more detail (infra, Chapter 5), these are not justifications for neglecting the interpretative methods of international law. Quite the contrary: given the indeterminacy of international law, the countermajoritarian features of judicial decision-making, and the risk that judges abuse their interpretative power, the practice of Swiss and other domestic judges cannot escape scrutiny. Judicial interpretations must, among other things, be evaluated based on whether they comply with the law's interpretative methods, and based on whether they are predictable, clear, and consistent.

While many other legal and moral principles apply to and constrain judicial interpretation, my primary focus in this book lies on States' international legal obligations and on the interpretative methods required by international law, as well as on the abovementioned three virtues of predictability, clarity, and consistency. I do not assess whether domestic courts reached the right interpretative conclusion, all things considered.

\section{Structure and Approach}

The structure of this book builds on Joseph Raz's statement that understanding the concept of interpretation requires delving into the three following questions: what is interpretation, why interpret, and how to interpret? ${ }^{6}$ While I follow this triptych ('what?', 'why?', and 'how?'), I sometimes adjust Raz's

5 Odile Ammann, 'International Law in Domestic Courts Through an Empirical Lens: The Swiss Federal Tribunal's Practice of International Law in Figures' (2018) 28 Swiss Review of International and European Law 489.

6 Joseph Raz, 'First Lecture: Even Judges Are Humans' (Storrs Lectures: Between Authority and Morality, 2003); Joseph Raz, 'Second Lecture: Theory of Interpretation - What Is Interpretation?' (Storrs Lectures: Between Authority and Morality, 2003); Joseph Raz, 'Third Lecture: Why Interpret? How to Interpret?' (Storrs Lectures: Between Authority and Morality, 2003). 
questions to make them fit the needs of a legal, doctrinal analysis, as well as the international legal context. ${ }^{7}$

My endeavor, contrary to Raz's, is not that of a legal philosopher who stands outside the law. My aim is to start from the domestic (primarily Swiss) judicial practice of international law and to examine it qua law and from within, ie, from the perspective of a participant rather than from that of an observer. I intend to provide an overview of this practice, but also to evaluate it based on two criteria that I develop further below, and to formulate recommendations for its further improvement.

Part one, entitled 'What Is Interpretation?', lays out the foundations of the study. In Chapter 1, I introduce the issue at stake and explain its relevance. Chapter 2 is devoted to terminological and conceptual clarifications. In Chapter 3, I underscore features of the Swiss legal order that will help the reader understand some idiosyncrasies of the Swiss judicial practice of international law.

In the second part, entitled 'Why Interpret?', I elucidate what Joseph Raz calls the centrality of interpretation to legal practices. In Chapter 4, I clarify States' international legal obligations when it comes to applying and therefore interpreting international law domestically. In this chapter, I also identify the legal effect of domestic rulings in international law.

The third and last part of the book is devoted to the question 'How to interpret?' In Chapter 5, I prepare the ground for answering this query by showing why there are good reasons for requiring States to operate within a legal frame when they interpret international law. In Chapter 6, I discuss the components of this frame and the virtues and vices of different interpretative methods. The two last chapters dig into, and evaluate, the Swiss judicial practice pertaining to treaties (Chapter 7 ), customary international law (CIL), and general principles of international law (Chapter 8). These

7 What constitutes a doctrinal piece of scholarship is, of course, a scholarly debate of its own. Following Martha Minow, doctrinal scholarship can be described as scholarly work which aims to: 'a. Organize and reorganize case law into coherent elements, categories, and concepts; b. Acknowledge distinction between settled and emerging law; c. Identify difference between majority and "preferred" or "better" practice - ideally with some explanation for the criteria to be used'. See Martha Minow, 'Archetypal Legal Scholarship: A Field Guide' (2013) 63 Journal of Legal Education 65, 65. On doctrinal scholarship, see also Christopher McCrudden, 'Legal Research and the Social Sciences' (2006) 122 Law Quarterly Review 632, 633 ff; Terry Hutchinson and Nigel Duncan, 'Defining and Describing What We Do: Doctrinal Legal Research' (2012) 17 Deakin Law Review 83; Allan Beever and Charles Rickett, 'Review Article: Interpretive Theory and the Academic Lawyer' (2005) 68 Modern Law Review 320; Stephen A Smith, 'Taking Law Seriously' (2000) 50 University of Toronto Law Journal 241. 
'practical' chapters also contain observations regarding the case law of domestic courts in general.

In the conclusion, I reiterate my argument and findings. I also suggest how to improve the Swiss practice, and that of domestic courts more generally.

The cases studied are rulings of the Swiss Federal Tribunal and of other selected federal, cantonal, and military Swiss courts. I also rely on international and Swiss legal scholarship and legal theory and, occasionally, on the practice of foreign and international courts. When engaging with the case law in other States, my aim is not to undertake a full-fledged project of 'comparative international law'. ${ }^{8}$ Rather, it consists in putting the Swiss practice into perspective. Understanding and evaluating this practice requires analyzing it within its broader context, and not in clinical isolation. On the other hand, I hope that the 'Swiss' perspectives highlighted in this book will feed into the work of international legal scholars and practitioners, including into the work of researchers who are contributing to the growing ${ }^{9}$ field of comparative international law.

The literature I use ranges across many theoretical approaches to law, from legal positivism to legal realism and cLs. Many strands of legal scholarship have engaged with the topic of judicial interpretation, and they have explained, criticized, or sought to justify some of its aspects. My objective is to identify how these approaches can contribute to a better understanding of (and, hence, a more informed approach to) how domestic courts must interpret international law. Some of these theories must be approached with care, as they do not necessarily fit the international interpretive context of the Swiss legal order and the evaluative criteria I adopt in this study.

I argue that interpretation should be pluralistic, ie, that an interpretative conclusion should result from the application of a plurality of interpretative methods (infra, Chapter 6, 2.5). I do not defend a specific normative interpretative theory, such as textualism or purposivism (on the relationship between such theories and the law's interpretative methods, see infra, Chapter 2, 5.1). Every method has its virtues and its limitations (infra, Chapter 6, section 2). Even judges who, like the late Antonin Scalia, wholeheartedly endorse a specific normative interpretative theory and are explicit about it, do not adopt a perfectly consistent approach across cases. Even they tend to invoke different interpretative arguments depending on the result they seek to reach. Instead of arguing that a specific method should be given more weight, I highlight why

8 Eg Anthea Roberts, Paul Stephan, Pierre-Hughes Verdier, and Mila Versteeg (eds), Comparative International Law (Oxford University Press 2018).

9 Anthea Roberts, Is International Law International? (Oxford University Press 2017) 289. 
respecting the law's methods is important in general, and perhaps especially in international law (infra, Chapter 5).

By focusing on a jurisdiction and polity committed to an idiosyncratic cluster of values, my goal is not to endorse and to defend a given political philosophy. Switzerland, a liberal, constitutional, semi-direct democracy committed to the rule of law (infra, Chapter 3, section 3), serves as a starting point to critically examine and articulate the methods any State must follow to interpret international law via its courts.

Swiss readers might wonder why this book is not written in one of the four Swiss national languages. ${ }^{10}$ If Swiss lawyers, and especially Swiss judges, are my intended audience, writing in a Swiss national language is arguably more appropriate. Facing a difficult choice which many authors must confront, ${ }^{11}$ and with both an international and a domestic audience in mind, I settled on English based on various considerations. First, my study highlights States' international legal obligations. It hence concerns other jurisdictions as well, not only Switzerland. Second, this book engages with, and seeks to contribute to, contemporary international legal scholarship on international law in domestic courts, which is predominantly (though not only) written in English. Third, due to the globalization of legal research, scholarly analyses of the Swiss practice of international law are increasingly written in English. ${ }^{12}$ One must be critical of this dominance of English, however. ${ }^{13}$ Partly because the great bulk of international legal scholarship published today is written in English, ${ }^{14}$ domestic rulings available in this language enjoy disproportionate attention. ${ }^{15}$

\footnotetext{
10 Ie, German, French, Italian, and Romansh.

11 Roberts, Is International Law International? (n 9) 263.

12 Eg Thore Neumann and Anne Peters, 'Switzerland' in August Reinisch (ed), The Privileges and Immunities of International Organizations in Domestic Courts (Oxford University Press 2013); Andreas R Ziegler, 'The Application of wTo Law in Switzerland' in Claudio Dordi (ed), The Absence of Direct Effect of WTO [sic] in the Ec and in Other Countries (Giappichelli 2010); Daniela Thurnherr, 'The Reception Process in Austria and Switzerland' in Helen Keller and Alec Stone Sweet (eds), A Europe of Rights: The Impact of the ECHR on National Legal Systems (Oxford University Press 2008).

13 For a recent critique, see Christian Tomuschat, "The (Hegemonic?) Role of the English Language' (2017) 86 Nordic Journal of International Law 196.

14 John Louth, 'Guest Post: How Many International Law Books Are Published in a Year?' (Opinio Juris, 2015) <opiniojuris.org/2015/04/o8/guest-post-how-many-internationallaw-books-are-published-in-a-year>; Michael Wood, 'Editorial Comment - The Present Position Within the ILC on the Topic "Identification of Customary International Law": In Partial Response to Sienho Yee, Report on the ILC Project on "Identification of Customary International Law"' (2016) 15 Chinese Journal of International Law 3, 13.

15 ILA, '(Study Group on) Principles on the Engagement of Domestic Courts With International Law, Final Report: Mapping the Engagement of Domestic Courts With
} 
Moreover, the fact that resources like the Oxford Reports on International Law in Domestic Courts (ILDC), the online database of domestic rulings on international law provided by Oxford University Press, are only available in English, might hinder some domestic judges from using them.

\section{The Benchmarks of Legality and Quality}

Finally, it is essential to clarify the benchmark I use to evaluate the judicial practice. As previously mentioned, I propose to conduct this assessment based on two criteria: legality (or lawfulness), ie, whether a judicial interpretation has been reached in conformity with the law's interpretative methods; and what I call quality, ie, the extent to which a judicial interpretation is predictable, clear, and consistent. In the following, I briefly explain what the two criteria consist in.

The criterion of legality allows me to examine whether a judicial decision has been reached in conformity with what legal interpretative methods require. A judicial interpretation that violates the legal frame that governs it (ie, the law's interpretative methods) disregards the law. Given judges' duty to abide by the law, and given States' duty to respect international law, such an interpretation fails from the perspective of legality. Observing the law's interpretative methods demands that no method be disregarded. This requirement applies even if there will often be tensions between different methods, and even if in some cases, some methods will not seem helpful or important compared to others. Moreover, these methods must be taken seriously: instead of merely paying lip service to them, courts must genuinely seek to identify the features of the law to which these methods point. Importantly, however, compliance with the applicable interpretative methods does not prevent different courts from reaching different, incompatible interpretative outcomes.

The second criterion I use to evaluate a judicial interpretation is its quality, ie, the predictability, clarity, and consistency of the legal reasoning that underpins it. When referring to quality, I will not examine whether a judicial interpretation is legitimate (ie, whether the judge has the moral right to rule over the law's subjects), or whether it is justified (ie, whether it is morally

International Law' (2016) 7 <www.ila-hq.org/index.php/study-groups>; Cecilia M Bailliet, 'National Case Law as a Generator of International Refugee Law: Rectifying an Imbalance Within the UNHCR Guidelines on International Protection' in Mary E Footer, August Reinisch, and Christina Binder (eds), International Law and ... Select Proceedings of the European Society of International Law, Vol 5, 2014 (Hart Publishing 2016). 
defensible). ${ }^{16}$ The concept of legitimacy is highly complex and controversial, and legal philosophers have discussed it extensively. In this book, I will not provide a general theory of international justice, of the role the State ought to play in international law, nor will I provide a general theory of the legitimacy of international law, of Swiss law, or of Swiss courts' interpretations thereof. This should not detract from the fact that I will be defending claims that can have implications for - and would be elements of - such theories, and that I will be defending claims as to how judges must (from the perspective of international law) and should (from the perspective of high-quality legal reasoning) decide cases. Moreover, I will be relying on concepts (such as good reasoning) that are used in legal practice, but that also exist outside the law, eg in moral reasoning.

Instead of providing an analytical account of legitimacy, I will evaluate judicial interpretations based on whether they are predictable, clear, and consistent. These three characteristics are linked to the legal and moral principle of the rule of law, of which I do not provide a theory here, but which I believe the practice of international law should promote, and to which legal practice aspires. ${ }^{17}$ These three virtues are congruent with the principles Joseph Raz derives from the rule of law, and which specifically pertain to courts and their decisions. ${ }^{18}$

The virtues of predictability, clarity, and consistency go hand in hand. ${ }^{19}$ A predictable interpretation must be clear and consistent with other interpretations, and it is difficult to imagine how consistency could be achieved without clarity. Nonetheless, the three virtues may also pull in opposite directions. Their precise weights and implications might lead to disagreements, and the terminology used to describe them fluctuates. However, their basic characteristics are well established in legal practice.

First, predictability (which, in this book, is used as a synonym for stability, certainty, constancy, and foreseeability) ensures that a judicial interpretation can, with a minimal degree of certainty, be anticipated by the law's subjects. ${ }^{20}$

16 Alan John Simmons, 'Justification and Legitimacy' (1999) 109 Ethics 739. Note that I am referring to normative legitimacy, and not to sociological legitimacy. However, while sociological legitimacy is not the focus of this study, it is likely that the legality and quality of courts' reasoning contribute to the sociological legitimacy of their decisions.

17 On this complex topic, see Denise Wohlwend, The International Rule of Law: Notion, Scope, and Subjects (Edward Elgar, forthcoming).

18 See the principles 1 and 2 highlighted by Joseph Raz, ie, the requirement that laws be prospective, open, clear, and relatively stable: Joseph Raz, 'The Rule of Law and Its Virtue', The Authority of Law: Essays on Law and Morality (Clarendon Press 1979) 214 f.

19 Eg BGE 141 V 509, at 7.1.1.

$20 \quad$ Lon Fuller, The Morality of Law (Yale University Press 1964) 79 ff. 
Predictability does not mean that courts cannot overrule previous decisions in exceptional cases. However, the law's subjects must be able to expect such changes to happen, and departures from past cases must be carefully justified. ${ }^{21}$ By contrast, arbitrary, whimsical interpretations prevent the law's subjects from adjusting their behavior to what the law requires. They make it impossible to predict ${ }^{22}$ how law-applying bodies will determine the law.

Second, the clarity ${ }^{23}$ (or intelligibility, transparency) of judicial interpretations makes them understandable. Contrary to opacity, clarity enables the law's subjects to grasp what the law requires, and to adjust their behavior accordingly.

Third, a consistent (or coherent) judicial interpretation is devoid of contradictions. ${ }^{24}$ It lacks both internal contradictions, and contradictions with the reasoning of the court in previous cases. While internal consistency allows the law's subjects to make sense of judicial interpretations and to anticipate them, consistency with previous cases chiefly aims at ensuring that these subjects will be treated equally.

The value attached to predictable, clear, and consistent decisions, and the expectation that judicial interpretations will honor these virtues, are reflected in domestic and international legal practice. ${ }^{25}$

As regards predictability, under Swiss law, for instance, laws must be such that their subjects are able to at least roughly anticipate the legal consequences of their actions. ${ }^{26}$ Predictability (or certainty) is also a principle of English law, for example. ${ }^{27}$ In international law, predictability is reflected in the principle of non-retroactivity. ${ }^{28}$ The importance of predictability can be derived

21 On this problématique, see ibid 56 f; Pascal Pichonnaz, 'Leffet rétroactif du changement de jurisprudence: quelques réflexions à l'aune du pluralisme méthodologique' in Alexandra Rumo-Jungo and others (eds), Une empreinte sur le Code civil: Mélanges en l'honneur de Paul-Henri Steinauer (Schulthess 2013).

22 Some authors argue that the task of a lawyer consists in predicting how courts will adjudicate a dispute. See Oliver Wendell Holmes, 'The Path of the Law' (1897) 10 Harvard Law Review 457.

23 Fuller (n 20) $63 \mathrm{ff}$.

24 On contradictions in the law, see ibid $65 \mathrm{ff}$.

25 Geranne Lautenbach notes the difficulty of codifying these requirements: Geranne Lautenbach, The Concept of the Rule of Law and the European Court of Human Rights (Oxford University Press 2013) 39.

26 Eg in criminal law: BGE 141 IV 279, at 1.3.3. Regarding the restriction of fundamental rights, see SFAC, judgment A-4941/2014 of 9 November 2016, at 10.

27 Jonathan Mance, 'Should the Law Be Certain?' (Oxford Shrieval Lecture, 2011) <www.supremecourt.uk/docs/speech_111011.pdf>. 
from the fact that under domestic ${ }^{29}$ and international ${ }^{30}$ law, courts must decide cases according to law, independently, and impartially. The virtue of predicable interpretations is stressed in scholarship as well.

The value attached to clarity is expressed by the constitutional right to be given reasons for official decisions. ${ }^{31}$ It is also linked to the fact that under both domestic $^{32}$ and international ${ }^{33}$ law, judicial proceedings must, in principle, be public. In scholarship, judgments are frowned upon if the underlying reasoning is not transparent and intelligible.

Consistency is pursued in legal practice as well. Courts, when providing reasons for their interpretations, strive to show that these interpretations are required by the law, and that they are the result of sound reasoning. If judges were to do otherwise, their judgments would attract criticism, as lawyers and scholars often challenge court rulings based on their lack of consistency. Consistency is also reflected in the doctrine of stare decisis that exists in many jurisdictions, and in norms mandating stability across cases even in the absence of such a doctrine. ${ }^{34}$ It is also linked to the right to equality, which is protected by domestic constitutional law ${ }^{35}$ and by international law. ${ }^{36}$

As the previous remarks show, evaluating, criticizing, and seeking to improve the quality of legal reasoning based on its predictability, clarity, and consistency is not only a requirement of the rule of law: it is also reflected in legal practice and scholarship. ${ }^{37}$

I will not seek to prove that predictability, clarity, and consistency are good, legitimate features, nor will I demonstrate that they are required by the rule of law in international relations. Such a project is, as previously stated, not what I am pursuing in this study. For my purposes, I will simply assume that if a court interprets a given provision and concludes that its meaning is $\mathrm{X}$, it should be able to offer a predictable, clear, and consistent explanation of this result. If the court does not do so, I will assume that its interpretation fails from the perspective of the quality of legal reasoning and, hence, that it carries little

\footnotetext{
29 Art. 5(1) (adherence to law) and 3o(1) Cst. (independence and impartiality).

30 Art. 6(1) ECHR; art. 14(1) ICCPR (independence and impartiality).

31 Art. 29(2) Cst.

32 Art. 30(3) Cst.

33 Art. 6(1) ECHR; art. 14(1) ICCPR.

34 Art. 23 FA-SFT.

35 Art. 8 and $29(1)$ Cst.

36 Art. 14 ECHR; art. 2(1), 14(1), and 26 ICCPR.

37 For an example, see Noora Arajärvi, 'The Requisite Rigour in the Identification of Customary International Law: A Look at the Reports of the Special Rapporteur of the International Law Commission' (2017) 19 International Community Law Review 9.
} 
weight for the determination of the sources of international law (art. 38(1)(a)(c) ICJ Statute) and qua auxiliary means (art. 38(1)(d) ICJ Statute).

Indeed, assessing the quality of a legal interpretation helps in determining the weight this interpretation should be given with respect to the meaning of the interpretandum. ${ }^{38} \mathrm{~A}$ judicial interpretation that is not transparent, that contains a non sequitur, or that otherwise fails to demonstrate why the legal meaning of the interpretative object is $\mathrm{X}$, is of poor quality from the perspective of legal practice, both domestic and international. This is the case even if this interpretation is otherwise in conformity with legal interpretative methods. The quality of judicial decisions also influences the extent to which these decisions can (and should, from the perspective of the rule of law) contribute to the ascertainment of international law. (On the status of domestic rulings in the sources of international law and qua auxiliary means, see infra, Chapter 4, section 3).

The two criteria of legality and quality will underpin my evaluation of the judicial practice throughout the present study. In emphasizing that domestic courts must respect legal interpretative methods, I will point to the first criterion, ie, legality or lawfulness. In stressing that they must reason in a predictable, clear, consistent way, I will point to the second criterion, namely to the quality of the court's reasoning. One could argue that these criteria (and especially the three virtues of judicial reasoning) are indeterminate. Yet as Aristotle notes, '[o]ur discussion will be adequate if it has as much clearness as the subject matter admits of, for precision is not to be sought for alike in all discussions, any more than in all the products of the crafts.' ${ }^{39}$

Legality and high-quality reasoning are closely related. Predictable, clear, and consistent reasoning facilitates the observance of interpretative methods. Vice versa, interpretative methods increase the degree of predictability, clarity, and consistency of judicial decision-making. Given the close links that exist between legality and quality, and as is common in legal scholarship, I will often mention them jointly.

I now turn to the first part of this study, entitled 'What Is Interpretation?'

38 As Scott Brewer notes regarding the law of evidence, 'we might fashion an analogue for the Socratic maxim "the unexamined life is not worth living": the unexamined evidentiary argument is not worth believing'. See Scott Brewer, 'Logocratic Method and the Analysis of Arguments in Evidence' (2011) 1o Law, Probability and Risk 175, 175.

39 Aristotle,'NicomacheanEthics'bki ch $3<$ classics.mit.edu/Aristotle/nicomachaen.1.i.html>. I am grateful to Timothy Endicott for bringing this passage to my attention. 
Odile Ammann - 9789004409873

Downloaded from Brill.come4/25/2023 11:42:48PM via free access 